\title{
EFFECT OF DROUGHT STRESS ON GROWTH AND YIELD OF WHEAT GENOTYPES
}

\author{
Afrose Jahan ${ }^{1 *}$ and F. Ahmed ${ }^{2}$ \\ 1Department of Soil Science, Sher-e-Bangla Agricultural University, Dhaka-1207, Bangladesh \\ 2Plant Physiology Division, BARI, Gazipur-1701, Bangladesh \\ *Corresponding author, E-mail: jahansau@yahoo.com
}

(Received: 10 November 2017, Accepted: 23 December 2017)

Key words: Wheat, genotype, drought

\begin{abstract}
A pot experiment on screening of wheat genotypes against drought stress was conducted at the research field of Sher-e-Bangla Agricultural University in earthen pots during rabi season of 2013-2014. Fifteen (15) wheat genotypes were evaluated under drought (stress was imposed by withdrawing irrigation after emergence) and well irrigated (control) condition. Exposure of plants to drought led to remarkable reduction in yield contributing characters which ultimate caused in reduced yield in all the genotypes. However, genotypes showed remarkable variability in yield reduction due to drought. The highest relative yield was observed in genotype SATYN-25 followed by SATYN-2, BARI Gom-26 and BARI Gom-28. However, yield reduction was less in SATYN-25 (about 20\%) followed by BARI Gom-26 (21\%) and SATYN-2 (25\%). Besides yield performance of the genotypes, some drought tolerance indices like Geometric Mean Productivity (GMP), Stress Tolerance Index (STI), Yield Stability Index (YSI) and Stress Susceptible Index (SSI) were used to select the desirable genotypes. Among the genotypes, BARI Gom-26, BARI Gom-28 and SATYN-25 gave better yield with higher STI, GMP and YSI with lower SSI indicating that these genotypes would be suitable for growing under drought prone areas.
\end{abstract}

\section{Introduction}

Drought stress is a major abiotic factor that limits agricultural production (Jaleel et al., 2009; Golbashy et al., 2010), more importantly in the rain-fed areas of the world (Nikus et al., 2004). Drought is the most severe stress and the main cause of significant losses in growth, productivity of crop plants and finally their yields (Ludlow and Muchow, 1990). Drought affects morpho-physiological, bio-chemical and molecular processes in plants resulting in growth inhibition, stomata closure with consecutive reduction of photosynthesis, transpiration, decrease in chlorophyll content and inhibition of photosynthesis and protein changes (Lawlor and Cornic, 2002; Zhu, 2002) to cope with osmotic changes in their tissues. Wheat is one of the important cereal crops in Bangladesh. Wheat grown over an area of 3.74 million hectare with an annual production of about 1 million metric tons with an average of $2.60 \mathrm{t} \mathrm{ha}^{-1}$ (Anonymous, 2011) in Bangladesh. This production is less than that of the developed countries because about one third of the total area under wheat in Bangladesh falls in the rainfed regions where water stress can limit plant growth and productivity due to very low or no rainfall (Khaliq et al., 1999). In Bangladesh wheat is grown in winter / rabi season (November to March) under rainfed condition. Usually no significant precipitation takes place during this period. Most of the farmers grow wheat without irrigation due to scarcity of water. Some farmers provide supplemental irrigation by using surface water from the nearby ditches and canals. When the 
source of surface water dried up the crop is subjected to drought. There is little scope to irrigate the crop with underground water. It is well known that the ground water table in Bangladesh is declining day by day. The tendency of excess use of underground water for irrigation should be discouraged for maintaining ecological balance and healthy environment. As a result wheat faces drought stress at later stages that reduces grain yield drastically. The best option for crop production, yield improvement and yield stability under deficient soil moisture conditions is to develop drought tolerant crop varieties. New varieties must be developed that can withstand adverse climatic condition, particularly the soil moisture stress in order to produce increased yield per unit area.

Drought indices which provide a measure of drought based on loss of yield under drought conditions in comparison to normal conditions have been used for screening drought tolerant genotypes (Mitra, 2001). Keeping this view in mind, the present study was undertaken to evaluate the performance of wheat genotypes under drought condition, quantify yield loss due to drought and to screen out drought tolerant genotypes/varieties of wheat.

\section{Materials and Methods}

The experiment was conducted in earthen pots under vinyl house at the research field of Shere-Bangla Agricultural University campus during rabi season of 2013-2014. Fifteen (15) genotypes of wheat (collected from Wheat Research Center, BARI) were evaluated under well irrigated (control) and drought conditions (Table 1). Drought treatment (which was started after emergence up to maturity) was imposed by restricting irrigation, and plants were re-irrigated only when plant showed signs of wilting or leaf rolling. Control pots were irrigated as frequently as required to maintain adequate soil moisture. No rainfall occurred during experimental periods. The experiment was done in Completely Randomized design (CRD) with five replications. Earthen pot (20 cm top dia., $15 \mathrm{~cm}$ bottom dia. and $35 \mathrm{~cm}$ in height) were used in this study.

Table 1. List of wheat genotypes used in the present study

\begin{tabular}{lll}
\hline & \multicolumn{1}{c}{ Variety/Genotypes } & Remark \\
\hline $\mathrm{G}_{1}$ & BARI Gom 19 (Sourav) & Variety \\
$\mathrm{G}_{2}$ & BARI Gom 20 (Gourab) & Variety \\
$\mathrm{G}_{3}$ & BARI Gom 21 (Shatabdi) & Variety \\
$\mathrm{G}_{4}$ & BARI Gom 22 (Sufi) & Variety \\
$\mathrm{G}_{5}$ & BARI Gom 23 (Bijoy) & Variety \\
$\mathrm{G}_{6}$ & BARI Gom 24 (Prodip) & Variety \\
$\mathrm{G}_{7}$ & BARI Gom-25 & Variety \\
$\mathrm{G}_{8}$ & BARI Gom 26 & Variety \\
$\mathrm{G}_{9}$ & BARI Gom-27 & Variety \\
$\mathrm{G}_{10}$ & BARI Gom-28 & Variety \\
$\mathrm{G}_{11}$ & BAW 1118 & Advanced line \\
$\mathrm{G}_{12}$ & BAW 1135 & Advanced line \\
$\mathrm{G}_{13}$ & SATYN-2 & Advanced line \\
$\mathrm{G}_{14}$ & SATYN-25 & Advanced line \\
$\mathrm{G}_{15}$ & SATYN-26 & Advanced line \\
\hline
\end{tabular}


Pots were filled with soil and cowdung in 4: 1 volume ratio and final weight of pot was $14 \mathrm{~kg}$. Fertilizers@ @ 2.3-1-1-0.5 g/pot NPKS in the form of urea, triple super phosphate (TSP), muriate of potash (MOP) and gypsum were applied in the soil of each pot and incorporated properly. At sowing, 2/3 of urea and all other fertilizers were applied as basal. Remaining urea was top-dressed at 20 days after sowing. Seeds were sown in soil on $23^{\text {rd }}$ November, 2013. Ten seeds were sown in each pot. One week after emergence, seedlings were thinned to three per pot. Five pots were employed per treatment for each genotype. Intercultural operations were done as and when required. At harvest, yield and yield contributing characters were recorded from 3 pots from each genotype. Data were analyzed statistically by using MSTAT-C Software and mean separation was done by LSD test. Stress tolerance Index (STI) and Geometric Mean Productivity (GMP) were calculated according Fernandez (1992):

$$
\begin{aligned}
& S T I=\frac{\left(Y_{s}\right)\left(Y_{\boldsymbol{p}}\right)}{\overline{(Y p)^{2}}} \\
& G M P=\sqrt{(Y s)\left(Y_{P}\right)}
\end{aligned}
$$

Yield Stability Index (YSI) was calculated according to Bouslama \& Schapaugh, 1984:

$$
\mathrm{YSI}=\mathrm{Ys} / \mathrm{Yp}
$$

Stress susceptibility index (SSI) (Fisher \& Maurer, 1978):

$$
S S I=\frac{1-\frac{Y s}{Y p}}{1-\frac{\overline{Y s}}{\overline{Y p}}}
$$

Where, Ys and Yp are the mean yield of genotypes under stress and non-stress conditions, respectively and $\overline{\boldsymbol{Y s}}$ and $\overline{\boldsymbol{Y} \boldsymbol{p}}$ are the mean yield of all genotypes under stress and non-stress conditions.

\section{Results and Discussion}

\section{Plant height}

Plant height of the genotypes varied both in irrigated and drought stressed pots (Fig. 1). In irrigated pots, plant height ranged from 88 to $95 \mathrm{~cm}$. The maximum plant height was observed in G14 followed by G15, G5 and G10 and the shortest in G7. Under drought stress, plant height reduced in all the genotypes compared to control and it ranged from 60 to $77 \mathrm{~cm}$ in different genotypes. Plant height greatly reduced in G8, G11 and G13 due to drought. Reduction in plant height in wheat due to drought was also reported by Khakwani et al. (2012) and Nouri-Ganbalani et al., (2009).

\section{Number of spikes/plant}

The number of spikes/plant of the genotypes was significantly different both under control and drought condition (Table 2). In control, the maximum number of spikes/plant was observed in genotype G8 (9.3) which were statistically identical with G10 and G3 but higher than others. The second highest spikes/plant was recorded in G13 and G14. The lowest spikes/plant was found in genotype G7 (5.0) which were identical with G2, G6, G7, G9 and G16. Under drought condition, number of spikes/plant was reduced in all the genotypes. Among the 
genotypes, G8 showed the highest spikes/plant (4) which was identical with G10 and G14 and the lowest in G6 (1.3). These results are in agreement with the findings of Khakwani et al., (2012) who observed that drought caused reduction in number of effective tillers plant ${ }^{-1}$ by 35 percent.

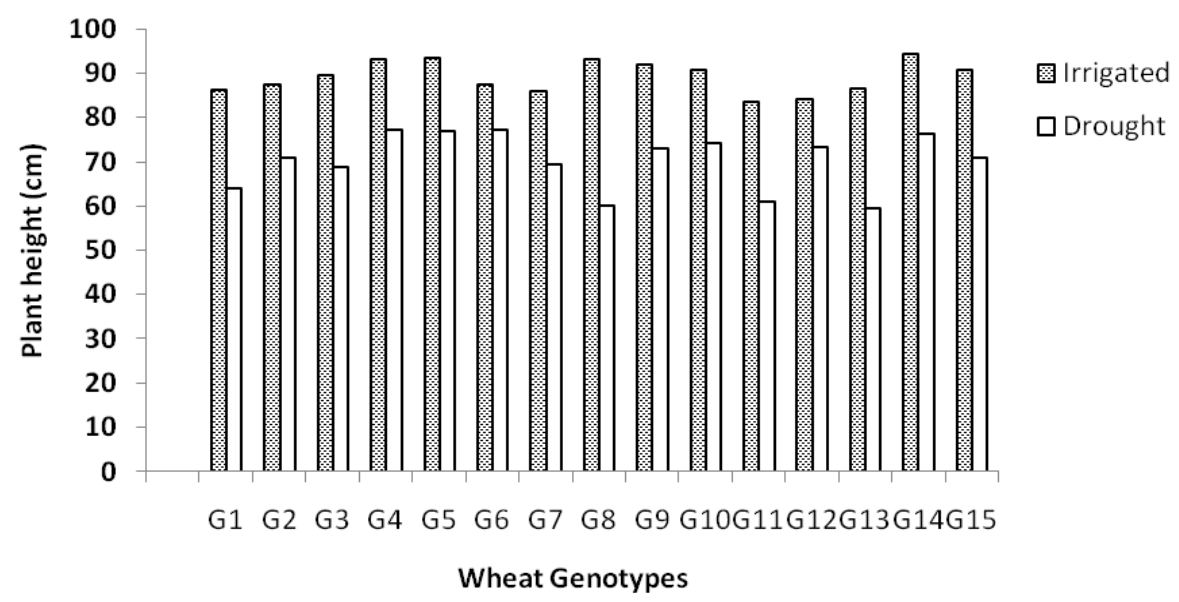

Fig. 1. Effect of drought on plant height (at harvest) of wheat genotypes

$\mathrm{G}_{1}=$ BARI Gom 19, $\mathrm{G}_{2}=$ BARI Gom 20, $\mathrm{G}_{3}=$ BARI Gom 21, $\mathrm{G}_{4}=$ BARI Gom 22, $\mathrm{G}_{5}=$ BARI Gom 23, $\mathrm{G}_{6}=$ BARI Gom 24, $\mathrm{G}_{7}=$ BARI Gom-25 $\mathrm{G}_{8}=$ BARI Gom 26, $\mathrm{G}_{9}=$ BARI Gom-27, $\mathrm{G}_{10}=$ BARI Gom-28, $\mathrm{G}_{11}=\mathrm{BAW} 1118, \mathrm{G}_{12}=$ BAW $1135, \mathrm{G}_{13}=$ SATYN $-2, \mathrm{G}_{14}=$ SATYN $-25, \mathrm{G}_{15}=$ SATYN -26

\section{Number of grains/Spike}

Genotypes varied in number of grains/spike both in irrigated and drought condition (Table 2). However, under irrigated condition, the highest number of grains/spike was produced by G14 (49.2) which higher than G2 and G2 but identical with other genotypes. The lowest grains/spike was recorded in G6 (35.6) and it was identical with G2 genotype. Under drought, all the genotypes produced lower number of grains/spike compared to control. Higher number of grains/spike was observed in G8 (40.6) which similar with G3, G10, G11, G12, G14 and G15 but significantly higher than other genotypes and the lowest in G6 (25.8). Khannachopra et al., (1994) reported that reduction in number of grains spike $e^{-1}$ in wheat under water stress but the extent of reduction was different in various genotypes.

\section{0-grain weight}

Genotypes showed variation in grain size both in irrigated and drought condition (Table 2). Drought reduced grain sizes of all the genotypes. Under irrigated condition, 1000-grain weight was maximum in G2 (56.60 g) which was identical with G7, G8, G14 and G15 but significantly higher than other genotypes. Moderate grain size was observed in G4, G6, G10, G11, G12 and G13 which ranged from 49.88 to $52.9 \mathrm{~g}$. The lowest 1000 -grain weight was recorded in G3 (43.2g) and it was identical with G5 and G9. In drought stress, the maximum 1000-grain weight was found in G2 (52.48g) which was statistically similar with G4, G6, G7, G8, G10, G14 and G15 but significantly higher than others. Remaining genotypes showed statistically similar grain size and the lowest was found in G3 genotype. This result is in agreement with those reported by Khan et al., (2005) who observed that 1000-grain weight in wheat was reduced mainly due to increasing water stress. 
Effect of Drought Stress on Growth and Yield of Wheat Genotypes

\section{Grain yield}

Grain yield/plant varied significantly among the genotypes both under control and drought stress conditions (Table 2). Under irrigated condition, the highest grain yield/plant $(8.72 \mathrm{~g})$ was produced by G14 which was significantly higher than G1, G2, G6, G7 and G13 but statistically identical with other genotypes. The lowest yield/plant $(7.22 \mathrm{~g})$ was recorded in G13 and it was identical with G1, G2, G6 and G7 genotypes. In drought stress, grain yield /plant were drastically reduced in all the genotypes and the maximum yield $(7.00 \mathrm{~g} / \mathrm{plant})$ was found in G14 but similar with G8 and G10. The lowest grain yield/plant (2.52 g) was observed in G7 genotype which was identical with G6 genotype. Rest of the genotypes gave moderate grain yield per plant which ranged from 4.28 to $5.39 \mathrm{~g}$. The reason for lower grain yield under water stress condition was mainly due to reduction in number of effective tillers plant ${ }^{-1}$, spike length, number of grains spike $e^{-1}$ and 1000 -grain weight.

Table 2. Effect of drought stress on yield and yield contributing characters of wheat genotypes

\begin{tabular}{|c|c|c|c|c|c|c|c|c|}
\hline \multirow[t]{2}{*}{ Genotypes } & \multicolumn{2}{|c|}{$\begin{array}{c}\text { Number of } \\
\text { Spikes/plant }\end{array}$} & \multicolumn{2}{|c|}{$\begin{array}{l}\text { Number of } \\
\text { Grains/spike }\end{array}$} & \multicolumn{2}{|c|}{$\begin{array}{l}\text { 1000-grain wt. } \\
\text { (g) }\end{array}$} & \multicolumn{2}{|c|}{$\begin{array}{c}\text { Grain yield/ } \\
\text { plant }(\mathrm{g})\end{array}$} \\
\hline & Irrigated & Drought & Irrigated & Drought & Irrigated & Drought & $\begin{array}{l}\text { Irrigated } \\
\text { (Yp) }\end{array}$ & $\begin{array}{l}\text { Drought } \\
\text { (Ys) }\end{array}$ \\
\hline $\mathrm{G}_{1}$ & 7.0 & 2.0 & 47.0 & 27.6 & 49.88 & 46.16 & 7.59 & 4.50 \\
\hline $\mathrm{G}_{2}$ & 5.7 & 1.7 & 36.6 & 32.2 & 56.60 & 52.48 & 7.23 & 4.28 \\
\hline $\mathrm{G}_{3}$ & 9.0 & 2.7 & 43.4 & 37.8 & 43.20 & 40.64 & 8.45 & 4.80 \\
\hline $\mathrm{G}_{4}$ & 6.7 & 2.7 & 43.0 & 32.2 & 52.90 & 46.80 & 8.67 & 5.09 \\
\hline $\mathrm{G}_{5}$ & 7.3 & 2.5 & 47.4 & 37.6 & 45.12 & 40.76 & 8.69 & 4.65 \\
\hline $\mathrm{G}_{6}$ & 5.5 & 1.3 & 35.6 & 25.8 & 51.64 & 51.08 & 6.51 & 2.91 \\
\hline $\mathrm{G}_{7}$ & 5.0 & 1.7 & 45.0 & 33.0 & 54.24 & 49.64 & 6.17 & 2.52 \\
\hline $\mathrm{G}_{8}$ & 9.3 & 4.0 & 48.4 & 40.6 & 53.12 & 52.28 & 8.69 & 6.83 \\
\hline $\mathrm{G}_{9}$ & 6.0 & 1.3 & 42.4 & 31.6 & 45.68 & 44.56 & 8.22 & 5.04 \\
\hline $\mathrm{G}_{10}$ & 8.7 & 3.0 & 45.8 & 39.6 & 51.36 & 46.96 & 8.72 & 6.36 \\
\hline $\mathrm{G}_{11}$ & 6.7 & 1.7 & 42.6 & 39.0 & 50.40 & 45.32 & 7.71 & 4.50 \\
\hline $\mathrm{G}_{12}$ & 7.0 & 1.3 & 47.6 & 38.0 & 49.00 & 45.28 & 8.58 & 4.98 \\
\hline $\mathrm{G}_{13}$ & 8.0 & 2.7 & 45.6 & 34.8 & 50.56 & 40.36 & 7.22 & 5.39 \\
\hline $\mathrm{G}_{14}$ & 8.0 & 3.3 & 49.2 & 40.4 & 54.80 & 46.80 & 8.72 & 7.00 \\
\hline $\mathrm{G}_{15}$ & 6.0 & 2.0 & 42.2 & 37.4 & 55.20 & 50.36 & 8.40 & 5.28 \\
\hline $\operatorname{LSD}_{(0.05)}$ & 1.20 & 0.33 & 7.21 & 5.69 & 4.66 & 5.87 & 1.28 & 1.30 \\
\hline CV (\%) & 7.66 & 5.89 & 7.25 & 8.44 & 5.44 & 4.98 & 6.77 & 7.99 \\
\hline
\end{tabular}

$\mathrm{G}_{1}=$ BARI Gom 19, $\mathrm{G}_{2}=$ BARI Gom 20, $\mathrm{G}_{3}=$ BARI Gom 21, $\mathrm{G}_{4}=$ BARI Gom 22, G $=$ BARI Gom 23, $\mathrm{G}_{6}=$ BARI Gom 24, $\mathrm{G}_{7}=$ BARI Gom-25 $\mathrm{G}_{8}=$ BARI Gom 26, $\mathrm{G}_{9}=$ BARI Gom-27, $\mathrm{G}_{10}=$ BARI Gom-28, $\mathrm{G}_{11}=$ BAW 1118, $\mathrm{G}_{12}=$ BAW 1135, $\mathrm{G}_{13}=$ SATYN $-2, \mathrm{G}_{14}=$ SATYN $-25, \mathrm{G}_{15}=$ SATYN -26

\section{Relative yield}

Among the genotypes, the highest relative yield was found in $\mathrm{G}_{14}$ followed by $\mathrm{G}_{8}, \mathrm{G}_{13}$ and $\mathrm{G}_{10}$ (Fig. 2). The lowest relative yield was observed in $G_{7}$ followed by $G_{6}$ and $G_{5}$. Other genotypes showed almost similar relative yield. 
102

Jahan \& Ahmed

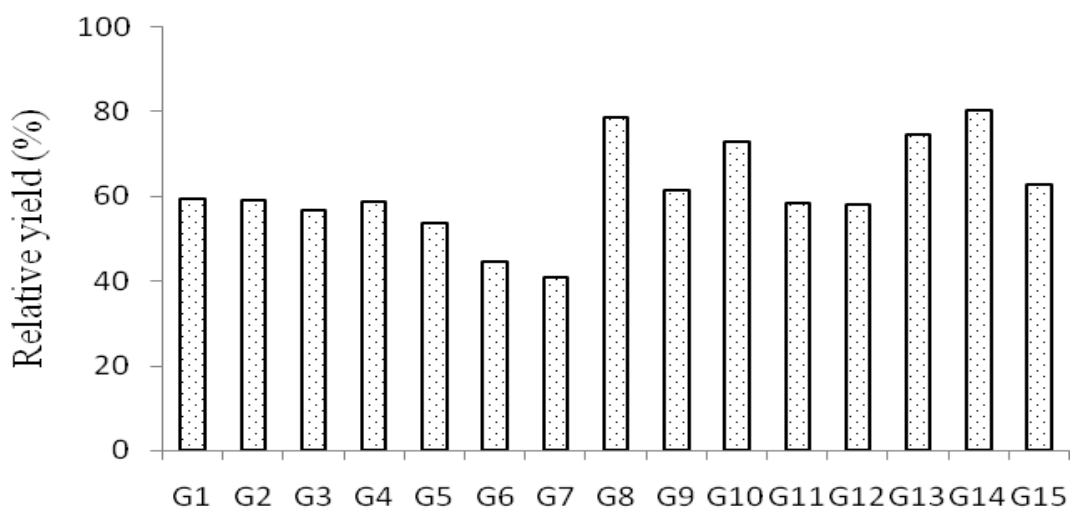

Fig. 2. Relative yield of the genotypes under drought condition

$\mathrm{G}_{1}=$ BARI Gom 19, $\mathrm{G}_{2}=$ BARI Gom 20, $\mathrm{G}_{3}=$ BARI Gom 21, $\mathrm{G}_{4}=$ BARI Gom 22, G $=$ BARI Gom 23, $\mathrm{G}_{6}=$ BARI Gom 24, $\mathrm{G}_{7}=$ BARI Gom-25 $\mathrm{G}_{8}=$ BARI Gom 26, $\mathrm{G}_{9}=$ BARI Gom-27, $\mathrm{G}_{10}=$ BARI Gom-28, $\mathrm{G}_{11}=\mathrm{BAW} 1118, \mathrm{G}_{12}=$ BAW 1135, $\mathrm{G}_{13}=$ SATYN $-2, \mathrm{G}_{14}=$ SATYN $-25, \mathrm{G}_{15}=$ SATYN -26

\section{Yield reduction (\%)}

Drought reduced grain yield of all the genotypes (Fig.3), however, yield reduction varied among the genotypes. The highest yield reduction was observed in G7 (about 59\%) followed by G6 $(55 \%)$ and G5 (46\%). The lowest yield reduction was observed in G14 (about 20\%) followed by G8, G13 and G10. The average yield loss in wheat due to drought stress estimated by Bayoumi et al., (2008) and Khakwani et al., (2012) were 43.20 and 58-82\%, respectively.

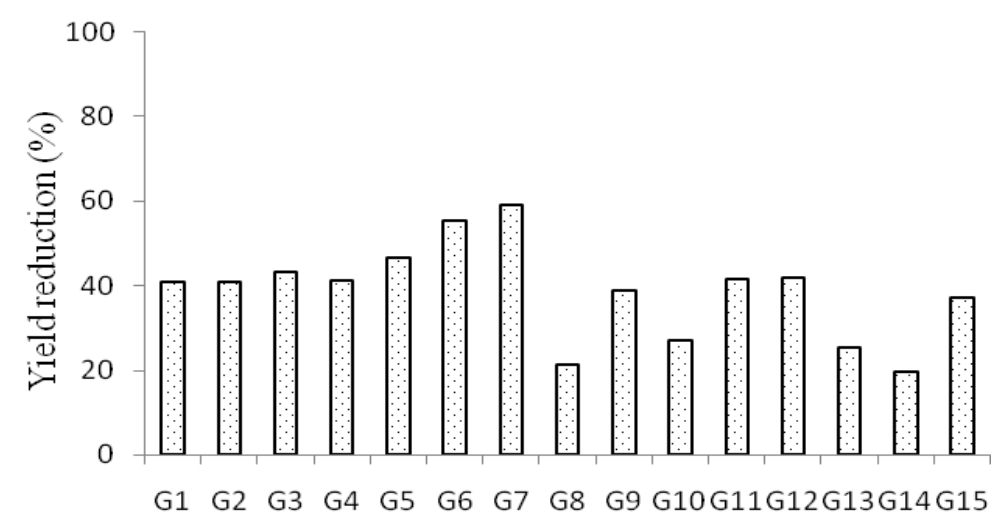

Fig.3. Relative yield of the genotypes under drought condition

$\mathrm{G}_{1}=$ BARI Gom 19, $\mathrm{G}_{2}=$ BARI Gom 20, $\mathrm{G}_{3}=$ BARI Gom 21, $\mathrm{G}_{4}=$ BARI Gom 22, $\mathrm{G}_{5}=$ BARI Gom 23, $\mathrm{G}_{6}=$ BARI Gom 24, $\mathrm{G}_{7}=$ BARI Gom-25 $\mathrm{G}_{8}=$ BARI Gom 26, $\mathrm{G}_{9}=$ BARI Gom-27, $\mathrm{G}_{10}=$ BARI Gom-28, $\mathrm{G}_{11}=$ BAW $1118, \mathrm{G}_{12}=$ BAW $1135, \mathrm{G}_{13}=$ SATYN $-2, \mathrm{G}_{14}=$ SATYN $-25, \mathrm{G}_{15}=$ SATYN -26 


\section{Straw yield (g/plant)}

In control condition, the maximum straw yield was obtained from G5 and G12 followed by G14. Moderate straw yield was observed in G1, G2, G4, G6, G8, G9, G10 and G15 and the lowest straw yield was found in G13 (Fig.4). Under drought stress, G2, G4, G9, G10, G11, G12 showed higher straw yield while the lowest in G3 and G5 genotypes.

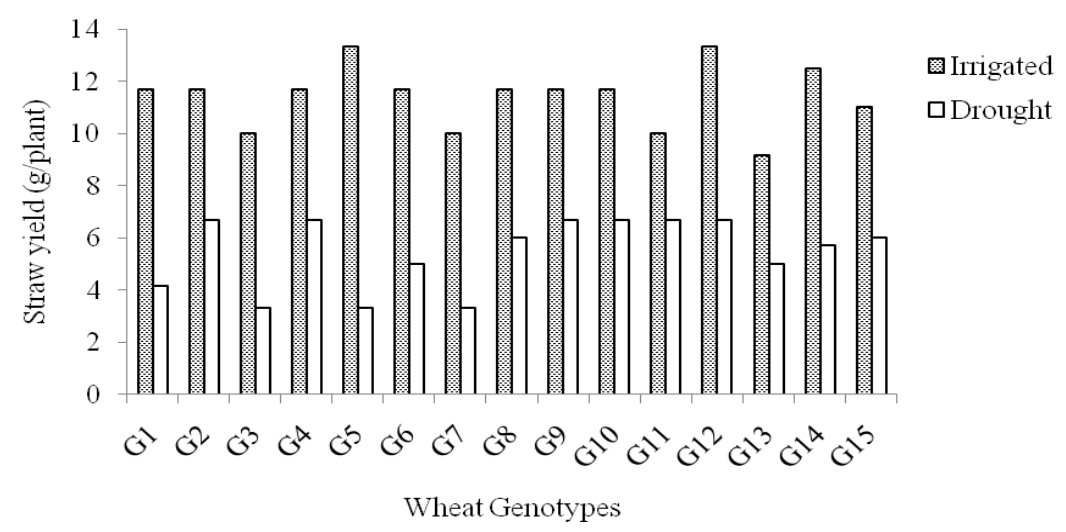

Fig. 4. Effect of drought on straw yield of wheat genotypes

$\mathrm{G}_{1}=$ BARI Gom 19, $\mathrm{G}_{2}=$ BARI Gom 20, $\mathrm{G}_{3}=$ BARI Gom 21, $\mathrm{G}_{4}=$ BARI Gom 22, $\mathrm{G}_{5}=$ BARI Gom 23, $\mathrm{G}_{6}=$ BARI Gom 24, $\mathrm{G}_{7}=$ BARI Gom-25 $\mathrm{G}_{8}=$ BARI Gom 26, $\mathrm{G}_{9}=$ BARI Gom-27, $\mathrm{G}_{10}=$ =BARI Gom-28, $\mathrm{G}_{11}=$ BAW 1118, $\mathrm{G}_{12}=$ BAW $1135, \mathrm{G}_{13}=$ SATYN $-2, \mathrm{G}_{14}=$ SATYN $-25, \mathrm{G}_{15}=$ SATYN -26

\section{Stress tolerance indices}

Stress indices like Geometric Mean Productivity (GMP), Stress Tolerance Index (STI), Yield Stability Index (YSI) and Stress Susceptible Index (SSI) are shown in Table 3.

Table 3.Tolerance indices of 15 wheat genotypes under variable water regimes

\begin{tabular}{lcccccc}
\hline Genotypes & Yp & Ys & GMP & STI & YSI & SSI \\
\hline BARI Gom 19 & 7.59 & 4.50 & 5.84 & 0.54 & 0.59 & 1.08 \\
BARI Gom 20 & 7.23 & 4.28 & 5.56 & 0.49 & 0.59 & 1.08 \\
BARI Gom 21 & 8.45 & 4.80 & 6.37 & 0.64 & 0.57 & 1.15 \\
BARI Gom 22 & 8.67 & 5.09 & 6.64 & 0.69 & 0.59 & 1.10 \\
BARI Gom 23 & 8.69 & 4.65 & 6.36 & 0.64 & 0.54 & 1.24 \\
BARI Gom 24 & 6.51 & 2.91 & 4.35 & 0.30 & 0.45 & 1.47 \\
BARI Gom-25 & 6.17 & 2.52 & 3.94 & 0.24 & 0.41 & 1.57 \\
BARI Gom 26 & 8.69 & 6.83 & 7.70 & 0.93 & 0.79 & 0.57 \\
BARI Gom-27 & 8.22 & 5.04 & 6.44 & 0.65 & 0.61 & 1.03 \\
BARI Gom-28 & 8.72 & 6.36 & 7.45 & 0.87 & 0.73 & 0.72 \\
BAW 1118 & 7.71 & 4.5 & 5.89 & 0.55 & 0.58 & 1.11 \\
BAW 1135 & 8.58 & 4.98 & 6.54 & 0.67 & 0.58 & 1.12 \\
SATYN-2 & 7.22 & 5.39 & 6.24 & 0.61 & 0.75 & 0.67 \\
SATYN-25 & 8.72 & 7.00 & 7.81 & 0.96 & 0.80 & 0.52 \\
SATYN-26 & 8.40 & 5.28 & 6.66 & 0.70 & 0.63 & 0.99 \\
\hline
\end{tabular}

$\mathrm{Yp}=$ Control yield, $\mathrm{Ys}=$ Water deficit yield, GMP= Geometric mean productivity, STI= Stress tolerance index, YSI= Yield stability index, SSI= Stress susceptibility index 
The maximum GMP was found in G14 (7.81) followed by G8 (7.70) and G10 (7.45) while the lowest GMP was found in G7 (3.94). STI also followed similar trend where G14 gave the maximum STI (0.96) followed by G8 and G10 and the lowest in G7. Higher YSI was observed in G14 followed by G8 and G10 and the lowest in G7. The maximum SSI was observed in G7 followed by G6 and G12. The lowest SSI value was found in G14 (0.52)

\section{Conclusion}

From the above results, it may be concluded that genotypes BARI Gom-26, BARI Gom-28 and SATYN-25 could be selected as drought tolerant genotypes on the basis of yield and stress tolerance indices. However, for confirmation of the result further study is needed.

\section{References}

Anonymous. 2011. Year book of agricultural statistics of Bangladesh, Bangladesh Bureau of Statistics (BBS), Ministry of planning, Government of the People's Republic of Bangladesh.

Bayoumi, T. Y., M. H. Eid and E. M. Metwali. 2008. Application of physiological and biochemical indices as a screening technique for drought tolerance in wheat genotypes. Afri. J. Biotech. 7: 2341-2352.

Golbashy, M., M. Ebrahimi, S. K. Khorasani, and R. Choukan. 2010. Evaluation of drought tolerance of some corn (Zea mays L.) hybrids in Iran. Afr. J. Agric Res. 5(10) : $2714-$ 2719.

Jaleel, C. A., P. Manivannan, A. Wahid, M. Farooq, H. J. Al-Juburi, R. Somasundaram and R. Panneerselvam. 2009. Drought Stress in Plants: A Review on Morphological Characteristics and Pigments Composition. Int. J. Agric. Biol. 11(1): 100-105.

Khakwani, A. A., M. D. Dennett, M. Munir and M. Abid. 2012. Growth and yield response of wheat varieties to water stress at booting and anthesis stages of development. Pak. J. Bot. 44(3): 879-886.

Khaliq, I., S. A. H. Shah, M. Ahsan and M. Khalid. 1999. Evaluation of spring wheat (Triticum aestivum L.) for drought field conditions. A morphological study. Pak. J. Biol. Sci. 2(3): 1006-1009.

Khan, A. J., F. Azam, A. Ali, M. Tariq and M. Amin. 2005. Inter-relationship and path co-efficient analysis for biometric traits in drought tolerant wheat (Triticum aestivum L.). Asian J. Plant Sci. 4(5): 540-543.

Khannachopra, R., S. S. P. Rao, M. Maheswari, I. Xiabing and S. K. Shivshankar. 1994. Effect of water deficit on accumulation of dry matter, carbon and nitrogen in the kernel of wheat genotypes differing in yield stability. Ann. Bot. 74(5): 503-511.

Lawlor, D. W. and G. Cornic. 2002. Photosynthetic carbon assimilation and associated metabolism in relation to water deficits in plants, Plant Cell Environ. 25: 275-294.

Ludlow, M. M. and R. C. Muchow. 1990. A critical evaluation of traits for improving crop yields in water limited environments, Adv. Agron. 43: 107-153.

Mitra, J. 2001. Genetics and genetic improvement of drought resistance in crop plants. Curr Sci. 80: 758-762. 
Nikus O, M. A. Turk, A. M. Al-Tawaha. 2004. Yield responses of sorghum (Sorghum bicolor, L) to manure supplemented with phosphate fertilizer under semi-arid Mediterranean conditions. Int J Agric Biol 6: 889-893.

Nouri-Ganbalani, A., G. Nouri-Ganbalani and D. Hassanpanah. 2009. Effect of drought stress condition on the yield and yield components of advanced wheat genotypes in Ardabil, Iran. J. Food Agric. Environ. 7: 228-234.

Zhu, J. K. 2002. Drought stress signal transduction in plants, Annu. Rev. Plant Biol. 53: 247-273. 